\title{
SKRB ZA SAMOGA SEBE I RELIGIOZNOST U FORMIRANJU IDENTITETA I ZADOVLJSTVA ŽIVOTOM KOD ADOLESCENATA I MLADIH
}

\author{
Jadranka Garmaz - Mihael Prović
}

Sveučilište u Splitu

Katolički bogoslovni fakultet jadrankagarmaz@gmail.com mihael.provic@gmail.com
UDK: 159.923.2-053.66+159.922.8 159.942-053.66:2-853

https://doi.org/10.34075/cs.56.3.8

Pregledni znanstveni rad Rad zaprimljen 5/2021

\section{Sažetak}

Vrijeme adolescencije i mladosti posebnoje životno razdoblje, kad svaki pojedinac prelazi iz faze djetinjstva ujedno novo razdoblje skrbi $z a$ sebe, $u$ kojem dolazi do formacije identiteta. U tom razdoblju svaka osoba zbog novih iskustava nanovo formira osobnu ljestvicu vrednota, $u$ koju se uključuje i područje religioznosti, s vlastitim vrednotama i normama ponašanja. Autori u prvom dijelu rada opisuju nekoliko vidova skrbi o sebi te religiozni život adolescenata i mladih. Drugi dio rada posvećen je formaciji (religioznog) identiteta pod genetskobiološkim i socio-kulturnim uvjetovanostima. Treći dio rada govori o zadovoljstuu životom adolescenata i mladih prema istraživanima Heinera Keuppa i Viere Pirker. Zaključuje se kako adolescenti i mladi preko različitih dimenzija religioznosti postižu osjećaj zajedništva $i$ pripadnosti, te kako im povezivanje vlastitog životnog iskustva sa sadržajima vjere donosi zadovoljstvo životom.

Ključne riječi: adolescenti i mladi, skrb za sebe, formacija identiteta, religioznost, zadovoljstvo životom.

\section{UVOD}

„Skrb za sebe“ stari je antički imperativ koji je jednako aktualan i u naše vrijeme. Prema Sokratu skrbiti za sebe znači „upoznati samoga sebe“. Za Sokrata ljudsko je dostojanstvo utemeljeno na unutrašnjim vrijednostima i „traganju“ za istinom o njima, koja kada se jednom pronađe, vrijedi za sve, te postaje nešto stalno, nepromjenjivo, sigurno, zasnovano na logičnoj nužnosti. Tako Sokratovu 
brigu za samoga sebe epimeleia heautou možemo gledati kao etički imperativ brige čovjeka za svoju dušu. Svojom metodom promišljanja, tzv. majeutikom, Sokrat polazi od ironične pretpostavke „znam da ništa ne znam" te tako u dijalozima sa sugovornicima pokazuje kako je njihovo znanje utemeljeno na lažnim i neprovjerenim pojmovima i varavim ljudskim opažanjima, te kako je potrebno planski vođenim razgovorom, tj. metodom indukcije - ispitujući pojedinačne oblike neke stvari ili pojave - doći do određivanja njezine biti, koja jednom definirana vrijedi za sve pojedinačne slučajeve jer je u sebi neproturječna i istinska objektivna spoznaja. Svoju metodu promišljanja Sokrat temelji na umu koji jedini dovodi do pravoga poznavanja stvari i do zbiljskog, općenito važećeg znanja. Ovo Sokratovo povjerenje $u$ pojam i ljudski razum na području moralnih pitanja dovodi do tzv. etičkog intelektualizma i optimizma, gdje su istina i moral identični pojmovi, gdje nitko ne griješi svojevoljno, gdje je grijeh zabluda, tj. neznanje. Stoga, kada bih znao, ne bih griješio, budući da ne znam, griješim. Budući da čovjek griješi, potreban je moralnog poučavanja, koje započinje od pretpostavke „(znam) da ništa ne znam“, te promišljanima, tj. „upoznavanjem samoga sebe“ dolazi do znanja o unutrašnjim vrijednostima i istine o sebi. Budući da čovjekovo znanje utječe na njegovo djelovanje, on postaje odgovorna moralna osoba - sposoban ne griješiti. Ova Sokratova racionalistička etika, utemeljena na idealističkoj pretpostavci zadnjeg pravorijeka razuma, nalazi zadnju potporu moralnih postupaka u „božanskom umu“, tj. logosu. ${ }^{1}$

Tema „skrb za sebe“ motivirala je autore ovoga teksta na promišljanje o umijeću vođenja dobroga i kvalitetnoga života u suvremenom svijetu, gdje suvremene mlade generacije nakon što završe fazu djetinjstva počinju nova životna razdoblja adolescencije i mladosti, u kojima se susreću sa samima sobom i sa svijetom oko sebe na jedan nov, drugačiji, potpuno „čudan“ i veoma „turbulentan“ način. U ovim fazama, „novih“ i „drugačijih“ susreta, adolescenti i mladi dolaze do novih iskustava, zbog kojih postaju svjesni mnogovrsnih promjena, koje su im do sada, na neki način bile „skrivene“, nevidljive i nesvjesne, a sada im se „otkrivaju“ i postaju ih svjesni na spoznajnoj, emocionalnoj i tjelesnoj razini njihova svakodnevnoga života. Tako u ovim životnim razdobljima adolescenti i mladi imaju jedno potpuno „novo“ i „drugačije“ iskustvo religioznosti i kršćanske duhovnosti nego u prijašnjim fazama djetinjstva. U ovoj novoj životnoj fazi adolescenti i mladi intenzivnije se nego ikada susreću

1 Usp. https://enciklopedija.hr/Natuknica.aspx?ID=57022 (pristupljeno 1. ožujka 2021.) 
s fazom formacije identiteta, sa svojim „novim ja“, kojeg sada drugačije doživljavaju nego kada su bili djeca. Stoga autori ovog rada metodom analize i komparacije proučavaju nekoliko važnih suvremenih istraživanja o odnosu osobne formacije i (ne)prihvaćanja religioznosti, tj. katoličke duhovnosti adolescenata i mladih gdje se oni preko „novog ja“ susreću s pitanima o smislu života, o smislu postojanja, o smislu religioznog života. Ovo „novo (religiozno) ja“ zapravo je nadogradnja njihovog „djetinjeg ja“, koji je sada na neki način drugačiji jer se propitkuje o sebi, upoznaje samoga sebe, propitkuje se o svom identitetu, svojim (ne)sposobnostima, i sl., tražeći sebe i svoje „mjesto pod suncem“, svoju „ulogu u suvremenom društvu“, kako bi još tako mlad i krhak život pronašao i ostvario svoj smisao i kako bi proživljavao zadovoljstvo vlastitog života.

\section{1. „SKRB ZA SEBE“ I RELIGIOZNOST}

U ovom radu promišljanje o „skrbi za sebe“ autori stavljaju u kontekst Sokratovih promišljanja i stavova poput „znam da ništa ne znam“ i „upoznaj samoga sebe“ kako bi se došlo do osobne potrebe za etičkim imperativom brige čovjeka za svoju dušu, gdje bi mlada osoba našega vremena koja živi u multikulturalnom i multireligioznom svijetu, upoznajući se s moralnim vrednotama Katoličke Crkve, svoje početno traganje za istinom, tj. „logosom“ pronašla $u$ vrednotama i religiozno-moralnom odgoju Katoličke Crkve, čiji nauk je utemeljen na vječnoj Istini - Isusu Kristu, tj. vječnom „Logosu“. Služeći se Sokratovim modelom, autori pokušavaju prikazati životni put adolescenata i mladih (tj. srednjoškolaca i studenata prema odgojno-obrazovnom sustavu Republike Hrvatske), koji nakon djetinjstva ulaze u životnu fazu u kojoj shvaćaju kako „Znaju da ništa ne znaju“ i kako su im potrebni odgoj i obrazovanje, te istodobno shvaćaju da moraju „upoznati same sebe“ kako bi otkrili svoje (ne) sposobnosti i zauzeli odgovornu ulogu u svojoj zajednici u kojoj bi se puni altruizma brinuli o sebi, svojim bližnjima i svijetu u kojem žive.

\subsection{Neki vidovi „skrbi o sebi“}

Kod svake osobe početak samostalne „skrbi za sebe“ vidimo na početku adolescencije, koja se nastavlja u razdoblju mladenaštva, kako bi svoju konačnu odgovornu ulogu svaki pojedinac potpuno živio u svojoj odrasloj životnoj fazi. Stoga adolescenciju najžešće nazivamo prijelaznim razdobljem, od djetinjstva, preko mladenaštva do odrasle, (ne)zrele dobi. Odrasla dob bit će zapravo plod adoles- 
cencije i mladosti, te je vidljiva kroz zrela ili nezrela djela osobe koja je dosegnula odraslu dob. ${ }^{2}$

Riječ „adolescent“ pa i pojam „adolescencija“ svoj korijen imaju u latinskom glagolu adolescere, što u hrvatskom prijevodu znači rasti. Ovo životno razdoblje neki autori ${ }^{3}$ dijele na ranu adolescenciju (koja traje od 12. do 14./15. godine) te kasnu adolescenciju (koja traje od 14./15. do 18. godine). ${ }^{4}$ Nakon adolescencije slijedi razdoblje mladosti, koje traje negdje do 30 . godine života. Ovo razdoblje istražuju brojne znanosti, poput biologije, antropologije, psihologije, pedagogije, sociologije pa i teologije. ${ }^{5}$

Promatrajući hrvatske prilike, mogli bismo ovu podjelu prilagoditi našem odgojno-obrazovnom sustavu te gledati ranu adolescenciju kao razdoblje od 5. do 8. razreda osnovne škole i kasnu adolescenciju kao razdoblje od 1. do 4. razreda srednje škole, nakon čega nastupa vrijeme studiranja, tj. vrijeme mladosti.

U ovim novim fazama života u središte svakog pojedinca dolazi potreba za neovisnošću i samostalna „skrb o sebi“, te stoga adolescenti i mladi odbacuju mišljenja i sugestije autoriteta iz djetinjstva (roditelja, učitelja, svećenika, itd.), što dovodi do turbulencija (kriza) u ponašanju koje su obilježene različitim pogreškama, strahovima

2 Dobne granice populacije adolescenata i mladih nisu jednoznačno određene. U Republici Hrvatskoj, prema nekim zakonima i službenim dokumentima postoje različite odredbe i tumačenja fenomena/termina životne dobi. Npr. Zakon o savjetima mladih u članku 3. pod mladima smatra osobe od 15 do 29 godina. Istu podjelu imamo i u dokumentu Nacionalni program djelovanja za mlade iz 2003. godine. Usp. Narodne novine, br. 23/2007., Adinda Dulčić, (ured.), Nacionalni program djelovanja za mlade, Državni zavod za zaštitu obitelji, materinstva i mladeži, Zagreb, 2003., str. 11. S druge strane Zakon o sudovima za mladež u članku 2. smatra kako su mlade osobe one do nenavršene 21 . godine života, a Ustav Republike Hrvatske u članku 45. spušta granicu mladosti na postizanje punoljetnosti sa 18 godina, kada pojedinac svojim biračkim pravom postaje zreo građanin Republike Hrvatske. Usp. Narodne novine, br. 56/90. 135/97, 8/98 pročišćeni tekst, 113/2000, 124/2000 - pročišćeni tekst, te broj 28/2001. Stoga je potrebno posvijestiti različitost $u$ tumačenja dobi kod adolescenata i mladih kada gledamo iz različitih perspektiva, poput pravne, psihološke, i biološke. Više o ovoj podjeli vidi u: Mislav Stjepan Žebec, Svijet mladih: izazov za Crkvu i društvo, Diacovensia, 16 (2008) 1-2, str. 37-65.

3 O adolescenciji i mladosti možemo pronaći mnoštvo istraživanja i literature, no za ovaj rad smo koristili samo neke osnovne tekstove, informacije i podatke kako bismo dobili jedan općeniti uvid u sam fenomen koji nam je bio potreban za ovaj rad.

4 Usp. Valentina Blaženka Mandarić, Religiozni identitet zagrebačkih adolescenata, Institut društvenih znanosti Ivo Pilar, Katolički bogoslovni fakultet u Zagrebu, Zagreb, 2000., str. 65.

5 Usp. Valentina Blaženka Mandarić, Mladi-integrirani i(li) marginalizirani, Glas Koncila, Zagreb, 2009., str. 69-70. 
i nesigurnošću pred odabirima životnih vrijednosti, vlastitog ponašanja i svjetonazora.

Autori koji proučavaju ovu tematiku obično se slažu kako je adolescencija krizno životno razdoblje za svaku osobu, te kako na njezin rast i formaciju identiteta utječu mnogi čimbenici. Valentina Blaženka Mandarić među čimbenike ubraja nekoliko vrsta kriza kroz koja adolescenti prolaze, a posebice su intenzivne psihološka, moralna i religiozna kriza. ${ }^{6}$

Prestankom, tj. rješavanjem ovih kriza adolescenti i mladi tražeći i otkrivajući sebe u novim životnim fazama, pokušavaju postati sposobni razlučivati bitno od nebitnoga, potrebno od nepotrebnoga, kako bi napokon samostalno, tj. neovisno o drugima, skrbili o sebi. Kako bismo bolje razlučili važnost samostalnosti i neovisnosti adolescenata i mladih pred fenomenom „skrbi o sebi“, potrebno je ukazati na nekoliko njezinih različitih vidova.

\subsubsection{Egoistični vid}

Egoizam (prema latinskoj riječi ego, što u hrvatskom prijevodu znači ja) odnosi se na „podvrgavanje svih istina i vrijednosti vlastitom sudu i vlastitim interesima“. ${ }^{7}$ Egoizam se zasniva na temeljnoj postavci kako svaki čovjek treba najprije misliti na sebe i da u svemu treba gledati vlastitu dobrobit, bez obzira na druge (pa i na njihovu štetu). Ovim tumačenjem naše „ja“ je vrhovno načelo i najviše moralno dobro, te se egoistično ponašanje svake osobe pokušava opravdati biološkom težnjom za samoodržanjem, gdje osjećaj za vlastito „ja“ postaje važnije od osjećaja za druge osobe. ${ }^{8}$

Prva egoistična ponašanja kod svake osobe možemo primijetiti već u djetinjstvu, kada dijete stavlja sebe u prvi plan jer ne uspijeva percipirati potrebe drugih. Stoga npr. potrebe vlastite braće i sestara dijete nesvjesno ne percipira te se ponaša egoistično, tj. „nezrelo“. U slijedećim životnim fazama dijete bi, zahvaljujući procesima socijalizacije i odgoja, trebalo postupno postajati više „Zrelija“, a manje egoistična osoba. Stoga možemo reći kako je egoizam kod djece „normalan“, tj. moramo ga tolerirati i gledati kao redovitu životnu fazu u kojoj dijete nije svjesno svojih ponašanja, no roditelji i odgojitelji pozvani su djetetu ukazivati kako je takvo ponašanje loše i nepri-

\footnotetext{
6 Usp. Valentina Blaženka Mandarić, Religiozni identitet zagrebačkih adolescenata, str. 73-77.

7 Usp. https://www.enciklopedija.hr/natuknica.aspx?id=17170 (pristupljeno 1. ožujka 2021.).

8 Usp. Isto.
} 
hvatljivo te ga preko drugih odgojnih metoda poučavanja (nagrada i kazna) potaknuti da svoje ponašanje uskladi s vrednotama zajednice u kojoj živi.

Poslije djetinjstva egoizam se nastavlja i u adolescenciji te mladosti, kad je osoba još uvijek „nezrela“ a ponaša se buntovno, negativno i destruktivno. U razdoblju adolescencije osoba, razvijajući kognitivne sposobnosti, postaje svjesna svog ponašanja i njegovih posljedica. U ovoj fazi osoba može vrednovati svoje ponašanje kao loše i nedopušteno u kulturi i zajednici kojoj pripada. ${ }^{9}$

\subsubsection{Egocentrični vid}

U egoističnom ponašanju svaki pojedinac najprije misli na sebe i vlastitu dobrobit, bez obzira na potrebe drugih. Uz pojam egoizam usko je povezan i pojam egocentrizam ${ }^{10}$ (egocentričnost), kojem je autor naziva i tumačenja Jean Piaget. Egocentrizam Piaget povezuje $\mathrm{s}$ kognitivnom fazom razvoja djece, $\mathrm{u}$ kojoj dijete ne razlikuje, tj. ne shvaća što je dio njega samoga, tj. njegova svijeta od svijeta izvan njega. ${ }^{11}$ Piaget u teoriji o kognitivnom razvoju osobe opisuje razdoblje od rođenja do adolescencije kroz četiri faze, a to su: senzomotoričko razdoblje, predoperacijsko razdoblje, razdoblje konkretnih operacija i razdoblje formalnih operacija. U svojim istraživanima Piaget pišući o fazama spoznajnih procesa zaključuje kako djeca nisu egoisti, nego egocentrici, tj. kako je njihovo ponašanje nesvjesno/nenamjerno, spontano i kako nisu u stanju shvatiti izvanjski svijet oko sebe $\mathrm{u}$ kojem se nalaze druge osobe sa svojim potrebama. ${ }^{12}$

Kao egoistična tako i egocentrična faza trebaju biti prolazne i vezane uz nezrelost pojedinca. S vremenom, kako osoba postaje zre-

9 Više o egoizmu vidi u: James L. Walker, La filosofia dell'egoismo, Ortica editrice, Aprilia, 2017., Serge moscovici, La relazione con l'altro, Raffaello Cortina Editore, Milano, 1996., Slobodan Sadžakov, Egoizam i altruizam, Filozofska istraživanja, 34(2014)3, 407-426., Bernard Špoljarić, Ego Complexities, Synthesis philosophica, 35(2020)1, str. 7-24., DRUGI VATIKANSKI KONCIL, Gaudium et spes, Kršćanska sadašnjost, Zagreb, 2008., br. 25., 37., 49., 82.-83.

10 Usp. https://hemu.lzmk.hr/natuknica.aspx?ID=13687 (pristupljeno 1. ožujka 2021.)

11 Iako su Piaget-ova kognitivna teorija i istraživanja kod nekih znanstvenika pobijana a njegovi rezultati dovedeni u pitanje, ostaje nam njegovo tumačenje o pojmu egocentrizma kojeg razlikuje od egoizma. Stoga i u govoru o religioznom odgoju adolescenata i mladih možemo uključiti oba pojma i promišljati o njihovim značenjima.

12 Usp. Jean Piaget, Lo sviluppo mentale del bambino e altri studi di psihologia, Einaudi, Torino, str. 69-72. 
lija, tako egoistično i egocentrično ponašanje prelaze $u$ altruistično ponašanje.

Procesima socijalizacije, odgoja te samoodgoja osoba može postati zrela i odgovorna za sebe, druge i svijet oko sebe, prihvaćajući vrednote i norme ponašanja (kršćanske) zajednice. Stoga je posebno potrebno za vrijeme srednjoškolskog i studentskog obrazovanja svakoj osobi ukazivati na nezrelost egoizma i egocentrizma te joj pomoći kako bi se socijalizirala i (samo)odgojila te postala „zrela/ altruistična“ osoba koja skrbi za sebe, bližnje i okolinu.

\subsubsection{Altruistični vid}

U adolescenciji i mladosti, zbog većih kognitivnih sposobnosti, svaka osoba postupno stječe potpuno nova iskustva. Iskustvo (latinski experientia) je skup spoznaja zasnovanih najčešće na izravnom, osjetilnom doživljavanju koje pojedinac iskušava ili doživljuje na izvanjski i(li) unutarnji način. Iskustvo je temeljno polazište spoznaje, metoda kojom se dolazi do znanja, a potom i ono postaje samo znanje. ${ }^{13}$

Vlastitim iskustvom svaka osoba za vrijeme adolescencije i mladosti na potpuno nov način doživljava egoistično, egocentrično te altruistično ponašanje. Osoba razlikuje pozitivna od negativnih iskustava te vidi ljepotu raznih djela koja su nastala kao plod solidarnosti, tolerancije, empatije, simpatije, zaljubljenosti pa i početničkih oblika ljubavi. ${ }^{14}$

Napokon, u ovom razdoblju osoba može shvatiti kako je pojam altruizam potpuno suprotan od pojma egoizam. Pojam altruizam (dolazi od francuske riječi altruisme (= prema), altrui (=drugi, bližnji) te latinske riječi alter, što u hrvatskom prijevodu znači drugi), označava pogled na svijet ili stav onoga tko smatra kako naše cjelokupno djelovanje mora biti usmjereno prema dobru drugoga. To je nauk $u$ kojem je moralno djelovanje usmjereno boljitku, tj. dobru drugoga. ${ }^{15}$

Katolička Crkva svojim odgojem pokušava nove generacije adolescenata i mladih naučiti kako postati altruistična osoba, prihvaćajući kršćanske vrijednosti i norme ponašanja. Sav katolički govor o altruizmu vidljiv je $\mathrm{u}$ religioznom iskustvu, $\mathrm{tj}$. duhovnom životu koji

13 Usp. https://www.enciklopedija.hr/Natuknica.aspx?ID=27924 (pristupljeno 1 . ožujka 2021.).

14 Više o altruizmu vidi u: Slobodan Sadžakov, Egoizam i altruizam, Filozofska istraŽivanja, 34(2014)3, 407-426.

15 Usp. https://www.enciklopedija.hr/Natuknica.aspx?ID=2038 (pristupljeno 1. ožujka 2021.). 
uključuje zrelu suosjećajnost i žrtvovanje za bližnje, te je utemeljen u osobi Isusa Krista - „Logosa“ te na Pavlovu Hvalospjevu ljubavi (usp. 1 Kor 13, 1-13) i evanđeoskom tekstu o najvećoj zapovijediljubavi prema sebi, bližnjima i Bogu (usp. Mt 22, 35-40).

\subsection{Religiozni život adolescenata i mladih}

Religiozni život adolescenata i mladih u današnjem multinacionalnom i plurikulturalnom svijetu je raznolik, te ga možemo promatrati kao komplementaran, napet i isključiv odnos, u kojem pojedinci religiju promatraju kao sustav vjerovanja, etičkih vrijednosti i čina, kako bi izrazili svoj odnos prema svetomu. ${ }^{16}$ Taj odnos pojedinca prema svetomu, prema „Logosu“, vidljiv je u religioznosti pojedinaca ili zajednice unutar određenog konfesionalnog vida, tj. preko normi ponašanja unutar konkretne religijske zajednice. ${ }^{17}$ Stoga $\mathrm{u}$ ovom radu promišljamo o raznolikosti mogućnosti religioznog života adolescenata i mladih, koji preko obitelji, župe, odgojnih institucija, vjerskih obreda i rituala te prihvaćanja katoličkih normi ponašanja utemeljenih na Svetom pismu i Tradiciji, žive svoju vjeru i zadovoljstvo životom kroz katoličku duhovnost - religioznost.

Kako bi se promišljalo o religioznosti i življenju kršćanskih vrednota s kojima postižemo zadovoljstvo životom, potrebno je krenuti od nauka Svetog pisma i Tradicije, koji se u našem vremenu izriču u dokumentima Drugoga Vatikanskog sabora i cijeloj pokoncilskoj teologiji. Uz to je potrebno analizirati kakav je život crkvene zajednice i njezina unutarnja kvaliteta danas, te kako je ona vidljiva kroz liturgijski život (sakramentalni život), koji treba biti izvor i vrhunac crkvenog života, kroz življu svijest naroda Božjega o važnosti poziva na svetost, preko življenja djelotvorne kršćanske ljubavi (caritas), kroz čitanje i meditiranje Riječi Božje (izvora kršćanskih vrednota) te kroz (suvremeno) poslanje Crkve u svijet(u), koja prihvaća unutarnju obnovu pred zahtjevima „novih modela evangelizacije“, koji uključuju otvorenost prema promicanju čovjeka pojedinca, dijaloga sa svijetom, različitim vjerama i svjetonazorima te što većim ostvarenjem jedinstva među kršćanima. ${ }^{18}$

16 Usp. https://www.enciklopedija.hr/Natuknica.aspx?ID=52381 (pristupljeno 1. ožujka 2021.).

17 Usp. https://www.enciklopedija.hr/natuknica.aspx?ID=52385 (pristupljeno 1. ožujka 2021.).

18 Usp. KONGREGACIJA ZA KLER, Opći direktorij za katehezu, Kršćanska sadašnjost, Nacionalni katehetski ured HBK, Zagreb, 2000., br. 27. 


\section{UVJETOVANOSTI FORMACIJE IDENTITETA ADOLESCENATA I MLADIH}

Adolescenti i mladi današnjeg vremena nalazeći se pred izazovima pluralizma, s obzirom na njegove religiozne i kulturne odlike, proživljavaju krizno razdoblje potrage, u kojem odgojem i formacijom vlastitog svjetonazorskog identiteta (koji u vjerskom kontekstu možemo nazvati religioznim identitetom) otkrivaju istinske vrednote kroz istinitost, ljepotu i dobrotu svijeta što ga kognitivno, emocionalno i djelotvorno, tj. iskustveno doživljavaju.

Zbog svoje radoznalosti adolescenti i mladi imaju potrebu za informiranjem o svemu što ih okružuje, tj. o svemu što im pluralizam sa sobom donosi pa tako i o različitim religijama i svjetonazorima, koje lako upoznaju preko njihovih kulturnih izričaja (glazba, odijevanje, načini prehrane, filozofija/teologija života, itd.) a najlakše do svih ovih informacija dolaze preko društvenih mreža, što ih dovodi do stanja nesigurnosti, zbunjenosti, tj. krize pripadnosti, krize identiteta, pa zatim i krize religioznosti, tj. vlastitog svjetonazora. Ta zbunjenost, nesigurnost i kriza osim što utječu na život adolescenata i mladih utječu i na život Crkve, koja je pozvana svojom katehizacijom i novom evangelizacijom pomagati rješavanju ove krize, te adolescentima i mladima ukazati vlastitim životnim primjerom i iskustvom vjere na katoličku religioznost, kojom mogu pronaći istinske vrednote kroz istinitost, ljepotu i dobrotu kršćanskog svijeta što ga kognitivno, emocionalno i djelotvorno, tj. iskustveno doživljavaju u župnoj zajednici kojoj oni i njihova obitelj pripadaju. ${ }^{19}$

Stoga se, govoreći o religioznom životu adolescenata i mladih današnjeg vremena, moramo fokusirati na jedan određeni, konkretan vid religioznog, tj. duhovnog života, onog kršćanskog, tj. katoličkog, koji opet moramo fokusirati na određeni teritorij, npr. teritorij Europske unije ili Republike Hrvatske te ga proučavati kroz genetsko-biološku i socio-kulturnu uvjetovanost pri formaciji religioznog identiteta adolescenata i mladih.

\subsection{Genetsko-biološka uvjetovanost}

Ne možemo govoriti adolescentima i mladima o kršćanstvu kao religiji i njezinoj pripadajući religioznosti bez govora o ljudskim pre-

19 Više o ovoj tematici vidi u: Ivan Supičić, Kriza vrednota i kultura, Bogoslovska smotra, 71(2001)2-3., str. 381-399; Željko Mardešić, Kulturološka kriza kršćanstva, Crkva u svijetu, 35(2000)2, str. 135-138, Joseph Ratzinger, Fede, verità e cultura, Milano, Tracce, 2000. 
duvjetima o kojima ovisi odgoj i formacija religioznog identiteta svake osobe. Stoga se pojmovi religija i religioznost odnose na istu pojavu - kršćanstvo, i kršćansku religioznost, tj. identitet na čiji odgoj i formaciju utječu genetske i biološke osobine pojedinca, te sama zajednica u kojoj se živi i njezin način života koji je vidljiv kroz njezinu kulturu. Tako konkretna katolička religija i njezina religioznost postaju životne putem biografsko-pojedinačnog i društvenokulturnog uobličenja i posredovanja. Stoga naš odgoj treba razvijati čovjekovu urođenu sposobnost i istodobno otkrivati i ostale mogućnosti koje ovise o izvanjskim faktorima. ${ }^{20}$

Početkom dvadesetog stoljeća razvojem bioloških znanosti nastaje nova era znanstvene discipline genetike; utemeljena je na znanstvenim istraživanjima češkog redovnika Gregora Mendela (1822. - 1844.), koji je u Brnu 1865. godine u djelu Versuche über Pflanzenhybriden objavio rezultate svojega osmogodišnjeg istraživanja i pokusa s graškom. Rezultati tih istraživanja donose osnovne principe o nasljeđivanju pojedinih osobina kod živih bića. Tzv. elementi nasljeđivanja kako ih je nazvao Mendel, danas su dobili novi naziv - geni. ${ }^{21} \mathrm{Ne}$ ulazeći u detaljniju analizu i povijesni razvoj Mendelova istraživanja, možda je još zanimljivo podcrtati četiri važna zaključka: 1. nasljedne osobine određuju faktori koji se nepromijenjeni prenose na potomstvo, a zovemo ih geni; 2 . svaki potomak od jednog roditelja nasljeđuje po jedan gen; 3. određena osobina ne mora se očitovani na pojedincu nasljedniku, ali se prenosi na buduće generacije u kojima se može manifestirati; 4 . jedna nasljedna osobina neovisna je o drugoj osobini istog roditelja. ${ }^{22}$

Danas genetiku definiramo kao znanost koja istražuje individualni proces nasljeđivanja i raznolikost genetičkih informacija, koja objašnjava sličnosti između roditelja i potomaka. ${ }^{23} \mathrm{U}$ svom procesu istraživanja genetika nam tumači kako se svojstva roditelja prenose na potomstvo, zbog čega jedinke istih roditelja nisu iste, već njihova naslijeđena svojstva variraju, te kako se ta naslijeđena svojstva

20 Usp. Religija - Religioznost, u: Religijsko-pedagoško katehetski leksikon, Katehetski salezijanski centar, Zagreb, 1991. str. 634.

21 Usp. Ivan Kešina, Genetika i genetičko inženjerstvo - povijest, šanse i opasnosti, u: Crkva u svijetu, 35 (2000.) 1, str. 10.

22 Usp. Mislav Kutleša - Dario Kral, Izazovi nove genetike u suvremenom društvenom i vrijednosnom kontekstu. Etička analiza i mogućnosti rizika, u: Crkva u svijetu, 55(2020.)1, str. 49.

23 Usp. http://www.genetika.biol.pmf.unizg.hr/pogl1.html (pristupljeno 1. ožujka 2021.). 
mijenjaju (ili stječu nova) pod utjecajem okoline, tj. drugih faktora koji ih okružuju. ${ }^{24}$

Genetika proučava i tumači procese nasljeđivanja živih bića, tj. čovjeka te biljnog i životinjskog svijeta. Ona je kao grana biologije u korelaciji s medicinom, psihologijom, filozofijom, teologijom i drugim znanstvenim disciplinama. Stoga proučavajući utjecaj genetike na religioznost pojedinca, možemo govoriti i o njezinom utjecaju na religiozne znanosti, tj. na katehizacju i novu evangelizaciju. Stoga u ovom radu možemo govoriti kako postoji genetsko-biološka uvjetovanost koja se odnosi na nasljedna svojstva koja djeca primaju od svojih roditelja. Ta nasljedna svojstva utječu na njihove tjelesne, kognitivne, emocionalne i druge (ne)sposobnosti, koje mogu imati svoju refleksiju na njihov razvoj i obrazovanje, tj. na njihov vjerski odgoj i formaciju religioznog identiteta.

\subsection{Socio-kulturna uvjetovanost}

Osim genetsko-biološke uvjetovanosti koju dijete stječe, tj. nasljeđuje od svojih roditelja biološkim putem, postoje i izvanjski utjecaju koji utječu na rast i razvoj pojedinca. Trenutni socio-kulturni ambijent $u$ kojem se adolescenti i mladi nalaze, poput ekonomskih, socijalnih i političkih (ne)prilika, trajno utječu na njihovu formaciju. Današnji adolescenti i mladi odrastaju u doba interneta, kabelske televizije, globalizacije, konzumerizma, terorističkih napada te brige o održivom razvoju, što sve zajedno utječe na njihov pogled na svijet i na donošenje bitnih odluka u životu. Stoga je potrebno pronaći načine komuniciranja, otkriti što ih zanima, o čemu razmišljaju, što ih tišti, kako doživljavaju svijet u kojem žive, što smatraju važnim, vrijednim, što ih motivira itd., kako bi svi zajedno živjeli s manje stresa i više zadovoljstva u vlastitom životu. ${ }^{25}$

Stoga je važno proučavati socio-kulturne uvjetovanosti i izvanjske faktore koji iz okoline, preko zajednice i njezine kulture, utječu na odgoj i obrazovanje pa onda i na vjerski identitet pojedinca. ${ }^{26}$

24 Usp. https://www.enciklopedija.hr/natuknica.aspx?ID=21609 (pristupljeno 1. ožujka 2021.).

25 Usp. Sandra Car, Adolescencija 21. stoljeća: društvena uvjetovanost, temeljne karakteristike i pedagoški izazovi, Pedagoška istraživanja, 10 (2013)2, str. 295-294.

26 Za primjer može poslužiti rad Inje Erceg Jugović, koja je istraživala utjecaj društva i kulture na adolescente s obzirom na njihovu (ne)zadovoljstvo vlastitim tjelesnim izgledom. Socio-kulturni čimbenici poput medija, roditelja, vršnjaka oba spola, koji postavljaju norme, ideale i standarde tjelesne ljepote, utječu na percepciju vlastitog tijela i na (ne)zadovoljstvo tijelom zbog mnogobrojnih i drastičnih 
Svaki pojedinac rađa se u točno određenoj zajednici, koja ima svoj identitet, svoju hijerarhiju vrednota i vrijednosti, svoju svjetonazorsku pripadnost. Stoga možemo govoriti o zajednici kao skupini ljudi koji žive na istom geografskom području, čiji članovi se poznaju i međusobno su povezani radom i drugim aktivnostima, tj. ulogama koje vrše, te zajedničkim interesima i simbolima kolektivne pripadnosti. Danas možemo govoriti o različitim oblicima agrarno-ruralnog i industrijsko-urbanog zajedničkog (su)života. Svi ovi načini zajedničkog života imaju potrebu za samostalnošću, neovisnošću, međusobnom solidarnošću i zajedničkom pripadnosti. ${ }^{27}$

Govoreći o zajedničkim interesima unutar zajednice, možemo reći kako postoje političke, ekonomske, kulturne, svjetonazorske (religiozne) i druge uvjetovanosti koje mogu utjecati na životnu ulogu pojedinca unutar zajednice. Stoga ja važno da Katolička Crkva što više proučava socio-kulturni utjecaj na odgoj i obrazovanje adolescenata i mladih u našim župnim zajednicama, kako bismo novim generacijama preko katehizacije i nove evangelizacije pomogli $u$ formaciji vlastitog religioznog identiteta.

Objašnjavajući socio-kulturni utjecaj na formaciju identiteta kod adolescenata i mladih, uz pojem zajednica važno je objasniti kako se pojam kultura odnosi na oplemenjivanje zajedničkog života kroz znanje, vjeru, umjetnost, moral, zakone i običaje. ${ }^{28}$

Možemo zaključiti kako na formaciju religioznog identiteta adolescenata i mladih u Republici Hrvatskoj, tj. u Europskoj uniji uz nasljedne genetsko-biološke uvjetovanosti utječu socio-kulturne uvjetovanosti, koje se prema navedenim pojašnjenjima odnose na točno određenu skupinu ljudi (stanovnici Republike Hrvatske) koji žive na točno određenom teritoriju (Republika Hrvatska/Europska unija) i koji svoj život oblikuju prema znanju, vjeri, umjetnosti, moralu, zakonima i običajima Katoličke Crkve.

\section{ZADOVOLJSTVO ŽIVOTOM KOD ADOLESCENATA I MLADIH}

Adolescencija i mladost razdoblja su intenzivnog formiranja identiteta, u kojem se skrb za sebe pokazuje u preslagivanju ljestvica

promjena za vrijeme adolescencije. Usp. Inja Erceg Jugović, Sociokulturni čimbenici nezadovoljstva tijelom $u$ adolescenciji, Ljetopis socijalnog rada, 22 (2015)3, str. 465-488.

27 Usp. https://www.enciklopedija.hr/Natuknica.aspx?ID=66736 (pristupljeno 1. ožujka 2021.).

28 Usp. Edward Burnett Tylor, Primitive culture. Reasearches Into Development of Mythology, Philosophy, Religion, Art, and Custom, Harper, New York, 1958. 
vrednota i prioriteta, ali se i razračunava s djetinjom religioznošću. Religioznost utječe na ponašanje i aktivnosti čovjeka te usmjerava na postizanje određenih ciljeva, zbog čega je ubrajamo u područje čovjekovih stavova i određenih vrednota. ${ }^{29}$ Slijedom te tvrdnje $u$ ovom je kontekstu promatramo kao važan oblik skrbi o sebi u vrijeme adolescencije i mladosti. U ovom ćemo dijelu u tri koraka skicirati važnost religioznosti kao oblika skrbi o sebi. U prvom ćemo svrnuti pogled na proces izgradnje identiteta prema Heiner Keuppu i Vieri Pirker, kako bismo pokazali kompleksnost tog procesa, a koji utječe na formiranje religioznosti i snažno utječe na zadovoljstvo životom. U drugome dijelu prikazat ćemo neke vanjske oblike skrbi o sebi, kao one preko kojih se razvija osjećaj zadovoljstva životom, a to su odnos prema drugima i odnos prema religiji. U trećem dijelu samo ćemo naznačiti rezultate nekih istraživanja religioznosti kod adolescenata i mladih, ${ }^{30}$ koji prikazuju povezanost između religioznosti i osjećaja dobrobiti.

\subsection{Fluidan i lomljiv identitet kao trajan proces razvoja}

U kompleksom procesu razvoja tijekom mladosti čini se da je najkompleksnije stvaranje identiteta. Koliko je taj proces složen, možemo vidjeti po tome što jednom kada se dovrši, osoba može sebi odgovoriti na tri pitanja. To je najprije pitanje o usklađenosti: Tko sam ja, za sebe i za druge?. Zatim je to pitanje o kontinuitetu: Kako sam postao onaj tko sam ja danas? Naposljetku, to je pitanje o izvornosti: Tko sam stvarno ja, i mogu li to pokazati?

Suvremene znanosti, a osobito psihologija i sociologija sve više se udaljuju od identiteta kao „statusa”. Identitet postaje mobilan, uvijek reprogramirani pojam: on je samo brzi pregled dugoročnog procesa koji je u sebi fluidan i lomljiv. U konceptu identiteta uvijek se javljaju oba aspekta: stanje i proces! Prema istraživanjima razvoja

29 Usp. Zdravka Leuar - Ana Marija Josipović, Neke dimenzije religioznosti mladih, u: Nova prisutnost, 6(2008.)3, str. 397-420; https://hrcak.srce.hr/34563 (pristupljeno 19. siječnja 2021.).

30 Utjecaj nekih dimenzija religioznosti (kao što je to duhovnost, obredna ili ritualna dimenzija i utjecaj vjere na ponašanje), na osjećaj zadovoljstva kod mladih. Analizom dosadašnjih istraživanja o religioznosti mladih prikazat ćemo utjecaj religioznosti na formiranje identiteta i općenito na zadovoljstvo životom kod mladih (Marčinko 2001., ali i Vuletić-Mujkić 2002.), jer mladi navode kako je najvažnije područje u procjeni kvalitete života: zdravlje, obitelj, religija i vjera. Religioznost se smatra izvorom dobrobiti u svim životnim dobima. 
i koncepta religioznog identiteta Viere Pirker ${ }^{31}$ sa Sveučilišta Goethe u Frankfurtu na Majni, identitet se shvaća kao trajan, cjeloživotni proces. U njemu je bitno da osoba može razviti i ojačati unutarnju koherentnost i kontinuitet u vlastitoj biografiji. Osim toga, od velikog je značenja vanjska vidljivost. Socijalni psiholog iz Münchena Heiner Keupp pretpostavlja da ljudi uvijek i stalno u svakom trenutku izgrađuju identitet svjesno, ali uglavnom nesvjesno. On opisuje unutarnji postupak na tri razine. Prva je razina tzv. situacijskog samorazvrstavanja (svaki mali trenutak - odluka hoću li pozdraviti nekoga u autobusu ili ne, odluka da kažem na zabavi da studiram teologiju ili ne, reagiram li ljutito ili ljubazno na zahtjev svoje majke, subrata i sl.). Druga je razina tzv. parcijalnog identiteta, koja se sastoji od mnogo različitih uloga u kojima se nalazimo svaki dan: kao muškarac ili žena; kao student; kao zaposlenik u kafiću; kao kćer ili sin u obitelji, kao brat i sestra; pripadnost određenom političkom stavu; ponašanje u slobodno vrijeme i sl.. Ovi su djelomični identiteti individualno sastavljeni, ali postoje tzv. područja u kojima većina ljudi ispunjava ulogu - npr. u području obitelji, tijela, posla. Na trećoj razini meta-identiteta susreću se dominantni parcijalni identiteti - to su neke uloge koje se javljaju u određenom trenutku života i tada dolaze do izražaja. Na primjer, ako osnivamo obitelj i imamo dijete, nova uloga kao „oca” ili „majke” dominirat će našim životom dugo vremena.

U procesu formacije identiteta postoje tzv. jezgrene (bitne) biografske priče, dakle, ono što je retrospektivno posebno važno u osobnom životu. Međutim, one se mogu promijeniti u toku života! Na primjer, pitanja geografskog ili nacionalnog podrijetla mogu postati vrlo važna pitanja u određenom trenutku života, kao što je preseljenje u domovinu ili izvan nje. Tu je također i vrlo jak „osjećaj identiteta" - to je individualni odnos čovjeka prema sebi, osjećaj koji imamo u odnosu prema samima sebi. Može biti da prema van sve izgleda sjajno, a mi smo interno vrlo krhki. Ili obrnuto! Taj osjećaj ima puno veze s tim kako reagiramo u svakodnevnom životu. Ovdje se često nalazi mjesto za izdržavanje velikih unutarnjih naprezanja.

31 Usp. Viera Pirker, Fluide und fragil. Identität als Grundoption zeitsensibler Pastoralpsychologie (doktorska disertacija), Ostfildern, 2013., Grünewald (Zeitzeichen, 31).

Usp. Viera Pirker, Fluid and fragile, or in between: christian identity in crisis? Perspectives from Pastoral Psychology, u: Jadranka Garmaz - Alojzije Čondić, Challenges to Religious Education in Contemporary Society, 116-131; http://ojs. kbf.unist.hr/index.php/proceedings/article/view/82 (pristupljeno 19. siječnja 2021.). 
Prema konceptu identiteta, tj. tzv. Patchwork identiteta, koji je izgradio Heiner Keupp, ${ }^{32}$ postoje dva cilja društvenog identiteta: to su priznanje i integracija. Oni su jako bitni u adolescenciji.

Priznanje, bilo da se odnosi na ono koje dobivamo izvana ili na samovrednovanje, utječe na razvoj čovjeka, budući se on bitno razvija putem osjećaja, koje dobiva kao odgovor iz svojega društvenog okruženja. To počinje vrlo rano, kada djeca artikuliraju svoje potrebe za roditeljima. Negativna povratna informacija je također oblik priznanja: Prvo, to je važan osjećaj „Imaš značenje” - „Ti si tu”. Prepoznavanje izvana kronološki je prije samoprepoznavanja. Iz tog razloga osobi koja uvijek dobiva samo negativan odgovor na svoju osobu, može biti vrlo teško razviti pozitivno priznanje i prihvaćanje sebe.

Integracija kao osjećaj pripadnosti određenim skupinama: Ljudi žele osjećati pripadnost određenim skupinama. Tinejdžeri se također bore vrlo teško oko pripadanja određenoj skupini; osobito „peer grupa” ima veliko značenje za njih. Skupina je prostor koja posreduje priznanje, a to je prostor u kojem se dogovaraju zajedničke vrijednosti i mjerila. Integracija je važan cilj u procesu identiteta.

Kognitivni ciljevi identiteta su commitment, odnosno odlučnost ili odanost izvornoj odluci ili važnom projektu određenim vrijednostima i zajednici, „u dobru i u zlu”, i autonomija, tj. sloboda s obzirom na oblikovanje života i svakodnevice koja je vrlo važna.

Emocionalni ciljevi identiteta su samopoštovanje i samoučinkovitost. Samopoštovanje znači da naše djelovanje, komunikacija i formiranje odnosa slijede taj unutarnji osjećaj da ljudsko biće ima samopoštovanje. Ili, recimo kolokvijalno, „da još uvijek mogu pogledati samog sebe u ogledalu”. Samoučinkovitost znači da osoba dobije odgovor izvana - da osoba shvati da je njezina predanost određenoj stvari, određenom projektu također potvrdno primljena i vrednovana.

Dakle, identitet se shvaća kao proces. U tom procesu bitno je da osoba može razviti i ojačati unutarnju koherentnost i kontinuitet u vlastitoj životnoj biografiji. Osim toga, od velikog je značenja vanjska vidljivost identiteta i snaga kojom se on pokazuje. Tako proces izgradnje identiteta donosi unutarnji i vanjski svijet unutar pojedinca u dodir, te osim unutarnjeg procesa izgradnje postoje i vanjski odnosi i procesi koji izgrađuju pojedince. Među njima se posebice ističu odnosi prema drugima i prema vjeri.

32 Teorija je predstavljena u zajedničkom zborniku radova. Usp. Heiner Keupp, Identitätskonstruktionen. Das Patchwork der Identitäten in der Spätmoderne. Hamburg 2002. Dostupno na poveznici: http://www.ipp-muenchen.de/texte/ keupp_dortmund.pdf (pristupljeno 25. svibnja 2021.). 


\section{2. „Skrb za sebe“ u odnosu prema drugima i religiji}

U odnosu prema drugima mladi odbacuju mišljenja i sugestije autoriteta iz djetinjstva (roditelji, učitelji, svećenici, itd.), što dovodi do turbulencija u ponašanju koje su obilježene različitim pogreškama, strahovima i nesigurnošću pred odabirima životnih vrijednosti, vlastitog ponašanja i svjetonazora. Tako se mladi mogu pronaći u odnosima egoistične naravi kada se ponašaju burno i destruktivno gledajući samo na svoje potrebe. Također se mogu pronaći u odnosima egocentrične naravi kada briga o sebi prelazi zdravu razinu. U altruistične odnose, međutim, mladi ulaze kada se odluče postati altruistična osoba koja se skrbi o sebi i bližnjima, ali i o okolini raznim djelima, kroz solidarnost, toleranciju, empatiju i druge oblike skrbi.

Skrb za sebe u odnosu prema religiji očituje se u odnosu pojedinca prema svetomu, prema Logosu; vidljiv je na pozitivan, negativan i neutralan način ovisno o (ne)prihvaćanju življenja duhovnog života. Možemo izdvojiti nekoliko primjera tih odnosa.

Pozitivan odnos mogu imati adolescenti i mladi koji redovito prakticiraju vjerski život u svojim obiteljima, župi i školi. Oni zbog dobrih iskustava imaju pozitivan odnos prema religioznom životu. Ovoj skupini pripadaju oni adolescenti i mladi koji su primili sve sakramente.

Negativan odnos mogu imati adolescenti i mladi koji su do sada redovito primili sve sakramente inicijacije, ali se sada zbog nekih vlastitih turbulentnih iskustava „opiru“ i odbijaju živjeti kršćanski život. Budući da im nedostaje „unutarnja motiviranost“, oni, povremeno žive neki tradicionalni oblik vjerskog života zbog „vanjske motiviranosti“, koja se najčešće odnosi na neki oblik „prisile obitelji i sredine“ u kojoj žive.

Neutralan odnos imaju adolescenti i mladi koji nisu „ni za - ni protiv“ vjerskog života i religioznosti, njih vjerski život jednostavno ne zanima. Oni će se ako treba krizmati ili povremeno prakticirati vjerski život (zbog vanjske motiviranosti), obavit će sve formalnosti, zadovoljit će sve uvjete koje Crkva, obitelj i zajednica propisuju, ali njih nikakav vjerski život ne zanima.

Religioznost se u svim dimenzijama ${ }^{33}$ odnosi na obje stvarnosti, na vanjsku i unutarnju formu identiteta, stoga je ona nedjelji-

33 Američki sociolozi King i Hunt smatraju da se religioznosti može pristupiti višedimenzionalno zbog čega oni razlikuju 11 načina da se bude religiozan. Među njih se ubrajaju: priznanje vjere, pobožnost, uključenje u Crkvu pohađanjem obreda, 
va od osjećaja zadovoljstva i osjećaja skrbi za sebe, što pokazuju i brojna istraživanja, ${ }^{34}$ od kojih ćemo neka samo naznačiti u idućem poglavlju. ${ }^{35}$

\subsection{Kako mladi sami vrednuju religioznost i ima li ona snagu skrbi?}

Ako u skrb za sebe ubrajamo vjerovanje, vjersku praksu, spoznaju, vjersko iskustvo i vjersko pripadanje, onda prema Glocku posjedujemo sva obilježja religioznosti koja je skrbna i pomaže čovjeku u njegovoj skrbi za sebe. ${ }^{36}$

To dokazuju i mnogobrojna istraživanja o utjecaju religioznosti na osjećaj dobrobiti. Istraživanja religioznosti kod mladih studenata filozofije i religijske kulture jednog zagrebačkog fakulteta ${ }^{37}$ pokazuju da sudionici u visokom postotku vjeruju u Boga, povremeno prakticiraju svoju vjeru, ali im je nezadovoljavajuća izgradnja vla-

organizacijsku djelatnost i novčanu pomoć, poznavanje vjere, usmjerenost na religiju, religiozno ponašanje, svjedočenje i svijest o važnosti religije za život.

Usp. Zdravka Leuar - Ana Marija Josipović, Neke dimenzije religioznosti mladih, str. 398.

35 O psihologiji religioznosti i dimenzijama religioznosti više u: Šimun Šito Ćorić, Psihologija religioznosti, Zagreb, Slap, 1998.

36 Usp. Sabino Acquaviva, Enzo Pace, Sociologija religije, Zavod za sociologiju, Biblioteka Societas, Zagreb, 1996., str. 78. Promatrano iz razvojne perspektive religioznost se razlikuje prema različitim razvojnim fazama. Tako s razdobljem puberteta kada se pojedinci okreću vršnjačkim skupinama, a manje su vezani uz obitelj, započinju razvojne promjene koje intenzivno utječu i na religioznost. Ti prijelazi iz faze $u$ fazu nose sa sobom mnoge promjene koje su vezane uz negativne emocije, tugu, i nezadovoljstvo. Razdoblje prelaska iz dječje dobi u mladost obilježeno je procesom izgradnje identiteta i formiranja stavova po kojima pojedinac želi biti neovisan i samostalan iako je ovisan o obitelji, izuzetno ranjiv i nestabilan. Upravo mu religioznost u smislu uključenja u crkvenu zajednicu, religioznog priznavanja vjere, pripadnosti, svjedočenja, kao i religiozno ponašanje mogu biti oblici skrbi ta sebe. Prema istraživanjima stupnjeva religioznosti koje on naziva stupnjevima vjere, James Fowler 1992., na temelju istraživanja J. Piageta, L. Kohlberga i E. H. Erksona, smatra da mladi poimaju Boga kao izvanjsku silu i snagu koja je neovisna. Naime, ulazeći u fazu apstraktnog mišljenja, mladi postavljaju pitanja o smislu života i utjecaju Boga na svijet. To je ključna točka, u kojoj su mladi na prekretnici da osobno pounutarnje vjeru ili da prihvate deizam kako odgovor o Božjem djelovanju u svijetu.

37 Usp. Vlasta Ilišin - Furio Radin, Mladi u suvremenom hrvatskom društvu, u: Vlasta Ilišin - Furio Radin, (ur.): Mladi: problem ili resurs. Zagreb, IDIZ, 2007., str. 13 - 37. Ovdje se misli na istraživanja na uzorku od 117 studenata FFDI s obzirom na dvije dimenzije, i to na osobnu religioznost i izgradnju vlastite religioznosti, u: Zdravka Leutar - Ana Marija Josipović, Neke dimenzije religioznosti mladih, str. $397-420$. 
stite religioznosti. ${ }^{38}$ Nasuprot tome, istraživanja mladih koji studiraju teologiju na jednoj visokoj školi u Njemačkoj pokazuju da su ti studenti distancirani od vjere ili religiozno neutralni. ${ }^{39}$

Koenig i suradnici su 2001. godine utvrdili kako se u $80 \%$ do 100 \% studija pokazalo da su religiozna vjerovanja i praksa dosljedno povezani s većim životnim zadovoljstvom, ugodnim osjećajima, srećom, i drugim pokazateljima dobrobiti. ${ }^{40}$ Također, prema Dušanic ${ }^{41}$ i Klarin/Krasicki, ${ }^{42}$ religiozne osobe su manje podložne depresivnosti, pogotovo one osobe kod kojih je izražena intrinzična religioznost. Nadalje, visoka korelacija između sreće i odlaska u crkvu dobivena je u istraživanju na uzorku od 160000 ljudi u 14 europskih zemalja, gdje su rezultati pokazali da se 85 \% ljudi koji idu u crkvu jednom nedjeljno, osjeća sretnije u odnosu na one koji ne idu. ${ }^{43}$

U istraživanju na populaciji studenata jednog fakulteta filozofije i religijskih znanosti u Zagrebu, pokazalo se da su religiozni-

38 Usp. Zdravka Leutar - Ana Marija Josipović, Neke dimenzije religioznosti mladih, str. 397. Navedeno istraživanje pokazalo je da se mladi većinom smatraju religioznima, da sakramentalni život postoji iako je intenzivniji kod novoobraćenika, da većina mladih moli izvan crkve, posebice novoobraćenici, da mladi žive $\mathrm{u}$ duhu vjere, ali su im prema njihovim procjenama potrebna dodatna znanja. Oni mladi koji su religioznost stekli obraćenjem, najviše se vrednuju na području osobne religioznosti, zatim slijede oni koji su u obitelji stekli religioznost, te oni koji odasvud izgrađuju religioznost te na koncu oni mladi koji su u procesu traženja religioznosti. Način stjecanja religioznosti pokazao se statistički značajnim gotovo u svim područjima, a u nekim od područja značajno je i socijalno porijeklo. Naime, mladi koji su od ranog djetinjstva odgajani u vjeri, imaju najčvršće ukorijenjene religijske vrijednosti i njeguju neke oblike crkvene prakse. Za razliku od njih mladi koji su novoobraćenici, više prakticiraju vlastitu religioznost te su na putu u potrazi za jednom i drugom dimenzijom.

39 Usp. Claus Peter Sajak - Michael Langer, (ur), Kirche ohne Jugend, Freiburg 2018. Citirano prema Gerald Meyer, Kirche ohne Jugend, u: Katechetische Blätter, str. 159.

40 Istraživanja kojima je ispitivana povezanost između intrinzične religioznosti i razine sreće koju osoba doživljava, pokazala su da se osobe s većom intrinzičnom religioznosti osjećaju sretnijima i lakše izlaze na kraj sa stresom. Istraživanja su također pokazala povezanost religioznosti sa zadovoljstvom životom. Usp. Ana Štifter, Religioznost i neki pokazatelji dobrobiti. Odsjek za psihologiju, diplomski rad, 2006. (http://darhiv.ffzg.unizg.hr/id/eprint/475/1/StifterAna.pdf, pristupljeno 25. svibnja 2021.).

41 Usp. Srđan Dušanić, Prediktori religioznosti mladih, u: Srđan Dušanić, Psihološka istraživanja religioznosti, Odsjek za psihologiju, Filozofski fakultet Banja Luka, 2007., str. 15 - 33.

42 Usp. Mira Klarin i Arkadius Krasicki, Religioznost i neke dimenzije psihološke dobrobiti kod mladih, u: Nova prisutnost, 17(2020.)2, str. 229-242.

43 Usp. Srđan Dušanić, Prediktori religioznosti mladih, str. 15 -33. 
ji pojedinci u prosjeku sretniji i zadovoljniji životom. ${ }^{44}$ Osim toga, religioznost se uz životni standard pokazala značajnim prediktorom zadovoljstva životom. Religiozniji studenti i oni s iznadprosječnim standardom zadovoljniji su životom. Prema Hackney i Sandersu religioznost i duhovnost su pozitivno, ali ne visoko povezane sa srećom. Religioznost je nešto više povezana s kvalitetom života, jer omogućuje socijalnu potporu, pomaže kod suočavanja sa stresom, preporučuje zdraviji životni stil i daje osjećaj smisla i svrhe. ${ }^{45}$ Peacock i Poloma $^{46}$ tvrde da mladi ljudi u religioznosti traže odgovore vezane uz stvaranje vlastitog identiteta te da veće zadovoljstvo duhovnim životom može biti razlog općenito zadovoljnijeg života. ${ }^{47}$

Iste rezultate, iako preliminarne, pokazuje i istraživanje $u$ Splitsko-makarskoj nadbiskupiji koje je provedeno kao kvantitativno istraživanje religioznosti krizmanika iz vremena prije pandemije koronavirusa, u veljači 2020. godine. Ispitivano je 476 krizmanika u 21 župi. Prema tim rezultatima, koji će biti objavljeni u cijelosti do kraja 2021., mladi su motivirani za pripravu zaprimanje sakramenta sv. potvrde, ali su uglavnom pasivni promatrači i rijetko sudjeluju aktivno u razgovoru, raspravi ili animaciji u susretima. Žele vjeru usvajati u zajedništvu, pokretu i na djelu, pa kao oblike religioznosti koji bi im izričito pomogli u skrbi za sebe, prepoznaju npr. planinarski križni put, akcije 72 sata, ali i duhovne obnove i molitvene susrete. Njih gotovo tri četvrtine sami su odlučili pohađati katehetsku priprava i primiti sakrament sv. potvrde $(76,3 \%)$, jer žele potvrditi svoju vjeru, ali među njima ima i onih koji ne žele razočarati bližnje, a osobito svoju baku. Vjera je prema većini istraživanih krizmanika privatna stvar (69\%), a oko $17 \%$ njih se osjećaju kao odgovorni članovi župne zajednice. Gotovo tri četvrtine ispitanika (74 \%) se u župnoj zajednici osjećaju ne kao aktivni odgovorni članovi, nego kao pasivni korisnici usluga.

44 Zdravka Leutar - Ana Marija Josipović: Neke dimenzije religioznosti mladih, str. 373 - 395.

45 Usp. Tihana Brkljačić - Ljiljana Kaliterna Lipovčan, Zadovoljstvo životom i osjećaj sreće kod studenata, u: Suvremena psihologija, 13(2010.)2, str. 189-200, (https://hrcak.srce.hr/83032, pristupljeno 25. svibnja 2021.).

46 Usp. James Peacock - Margaret Poloma, Religiosity and Life Satisfaction Across the Life Course, u: Social Indicators Research. An International and Interdisciplinary Journal for Quality-of-Life Measurement, 1999., 48 (1999.)3, str. 319-343. Usp. Tihana Brkljačić - Ljiljana Kaliterna Lipovčan, Zadovoljstvo životom i osjećaj sreće kod studenata, str. 18.

47 Autori razlikuju duhovnost i religioznost po tome što je duhovnost više unutarnja, a religioznost više vanjska kategorija, vezana više uz običaje, obrede, molitve i drugoga. Usp. Isto, bilješka 1, str. 341. 
Promatramo li trendove razvoja crkvenosti i osjećaja pripadnosti Crkvi, možemo reći da crkvenost ispitanih krizmanika ide u privatnost, a religioznost $\mathrm{u}$ distanciranost od institucionalne vjere. Religioznost kao oblik skrbi za sebe nalazi se kod njih na razmedu, i to $u$ napetosti između unutarnje koherentnosti, integracije u zajednicu i vanjske vidljivosti. Sve su to pokazatelji svojevrsnog raskrižja između mladih i Crkve, koje je potrebno uzeti u obzir. Naime, Novi Direktorij za katehezu predlaže da se Crkva u svom katehetskom poslanju osloni više na dijalošku i partnersku katehezu jer se katehetski cilj može ostvariti samo pod uvjetom da se sadržaji vjere dovedu u odnos i vezu sa životnim iskustvom mladih. ${ }^{48}$

\section{ZAKLJUČAK}

Istraživanja vjerskog života adolescenata i mladih pokazuju kako oni u tim životnim razdobljima, zbog unutarnjih spoznajnih, emocionalnih i tjelesnih promjena, ali i vanjskih eklezioloških uvjeta i sociokulturnih promjena, tj. pod genetsko-biološkim i socio-kulturnim uvjetovanostima, imaju različito oblikovana religiozna iskustva. Tijekom djetinjstva i adolescencije pripremaju se na buran proces stvaranja identiteta, pa su im, uza sva druga, ona religiozna iskustva od presudne važnosti kako bi stvorili pozitivan, negativan ili neutralan odnos prema religioznosti kao obliku skrbi za sebe. Istraživanja religioznosti kod mladih pokazuju da se religioznost koja je pozitivno implementirana u njihovu osobnost, temelji na uspješnom povezivanju životnog iskustva $\mathrm{i}$ istina vjere, s njihovom uključenošću u projekte Crkve, i to s uspjelim međugeneracijskim odgojem. ${ }^{49} \mathrm{Na}$ tome inzistira i Novi Direktorij za katehezu, koji ističe odgovornost svih, a osobito župnika u procesu poticanja dijaloške kateheze koja korelira sa životnim iskustvom, koja je oslonjena na komunikaciju Evanđelja i koja potiče dijaloški proces odgoja u partnerskom zajedništvu vjere i života. ${ }^{50}$ Stoga je način i proces učenja religioznosti odlučujući da bi mladi mogli religioznost prihvatiti i prepoznati kao oblik skrbi za sebe i druge. Osobito su religiozne infrastrukture i katehetski oblici koji nude iskustveni dodir s vjerom traženi kod mladih kako u Hrvatskoj tako i diljem Euro-

48 THE PONTIFICAL COUNCIL FOR THE PROMOTION OF THE NEW EVANGELIZATION, Directory for Catechesis, United States Conference of catholic Bishops, 2020., br. 3., 197., 333.

49 Usp. Bernd Lutz, Dialogische katechese: das neue Direktorium, u: Katechetische Blätter 2, 2021. , str. 56.

50 Usp. Novi Direktorij, br. 115-116, 128, 132, 171. 
pe. ${ }^{51}$ Iako su u europskim zemljama, osobito Njemačkoj i Austriji, mladi većinom religiozno neutralni ili distancirani od vjere, ipak se u svim zemljama pa i u Hrvatskoj pokazuje da su udruge mladih, vjernička društva i akcije koje su usmjerene na katehezu mladih u jačanju. Novi duhovni pokreti, studentski pastoral, akcije mladih, sportske aktivnosti, duhovni koncerti i festivali moderne duhovne glazbe, ljetovanja i kampovi s religioznim sadržajima pokazuju se kao adekvatan odgovor na potrebe mladih za religioznošću kao oblikom skrbi za sebe. Na kraju možemo zaključiti da je tradicionalno shvaćanje učenja i poučavanja religije u krizi. Nasuprot tome, religioznost posredovana i življena u malim skupinama, katoličkim udrugama mladih, duhovnim pokretima, posredovana čak i podcastom, društvenim mrežama, poznatim katoličkim influencerima, osobito u vrijeme pandemije, predstavlja veliki potencijal skrbi za sebe i nudi povećani osjećaj zadovoljstva životom te osjećaja dobrobiti kod mladih. ${ }^{52}$ Stoga Katolička Crkva novim generacijama adolescenata i mladih koji žive u Republici Hrvatskoj/Europskoj uniji, svojim odgojem i obrazovanjem utemeljenim na Kristu - „Logosu“, te na Pavlovom Hvalospjevu ljubavi (Usp. 1 Kor 13, 1-13) i evanđeoskom tekstu o najvećoj zapovijedi (usp. Mt 22, 35-40) može pomoći kako bi uspješno nadvladali svoje (adolescentske i mladenačke) psihološke, moralne i religiozne krize ${ }^{53}$ kako bi formirali religiozni identitet, te kako bi konačno kao zrele i odgovorne osobe živjeli etički imperativ brige čovjeka za svoju dušu (prema Sokratu i Kristu), zapravo, kako bi mogli „skrbiti o sebi“ i živjeti zadovoljstvo vlastitog života.

51 Usp. Mathias Bahr, Am gemeinsamen Haus „Europa“ bauen, u: Katechetische Blätter 2, 2021 , str. 87.

52 Usp. Claus Peter Sajak, Michael Langer, (ur), Kirche ohne Jugend, Freiburg, 2018.

53 Usp. Valentina Blaženka Mandarić, Religiozni identitet zagrebačkih adolescenata, str. 73-77. 


\section{SELF-CARE AND RELIGIOUSNESS IN THE FORMATION OF IDENTITY AND LIFE SATISFACTION IN ADOLESCENTS AND YOUNG PEOPLE}

\section{Summary}

The time of adolescence and youth is a special period of life in which each individual passes from the phase of childhood to a new period of self-care in which identity formation occurs. During this period, because of new experiences, each person re-forms the personal scale of values, which includes the area of religiosity with its own values and norms of behavior. In the first part of the paper, the authors describe several aspects of self-care and the religious life of adolescents and young people. The second part of the paper is dedicated to the formation of (religious) identity under genetic-biological and socio-cultural conditions. The third part of the paper talks about the life satisfaction of adolescents and young people according to the research of Heiner Keupp and Viera Pirker. It is concluded that adolescents and young people through different dimensions of religiosity achieve a sense of community and belonging, and that connecting their own life experience with the contents of faith brings them life satisfaction.

Key words: adolescents and young people, self-care, identity formation, religiosity, life satisfaction. 